\title{
A INFLUÊNCIA DAS REDES SOCIAIS NA SUBJETIVIDADE E NA SEXUALIDADE NOS SUJEITOS DE NOSSO TEMPO.
}

\author{
Nayara Dias Scrimim, Silvio Donizetti de Oliveira Gallo.
}

\begin{abstract}
Resumo
O presente trabalho busca refletir sobre o uso das redes sociais enquanto formas de subjetivação na contemporaneidade. Considerando que as redes sociais arrasta uma multidão de pessoas, vamos refletir sobre sua influência na constituição dos sujeitos e na relação destes com sua sexualidade. Para tanto, nos utilizaremos dos conceitos de subjetivação, corpos dóceis e sociedade disciplinar presentes na obra do filósofo Michel Foucault e, analisaremos duas redes sociais conhecidas por proporcionar o encontro daqueles que buscam um par, são elas: Tinder e AdoteUmCara. Entendemos que, pensar as redes sociais é refletir sobre os sujeitos de nosso tempo, por esse motivo, elas são um objeto de estudo de grande relevância.
\end{abstract}

Palavras-chave:

Foucault, Subjetivação, Sexualidade.

\section{Introdução}

Atraindo mais de 1,5 bilhões de pessoas em todo o mundo, elas transformaram nossa forma de nos relacionar, escrever, viajar, buscar informações, programar eventos, denunciar, votar, comprar... Enfim, as redes sociais vieram para ficar, tornando-se inerentes aos sujeitos deste tempo. Por esse motivo, tomaremos esta tecnologia como objeto deste artigo a fim de refletir sobre seus efeitos na constituição dos sujeitos e de sua sexualidade.

Por meio dos conceitos de subjetivação, docilização e mecanismo de poder presentes no livro Vigiar e Punir de Michel Foucault, procuraremos estabelecer relação com essas mídias, como sendo mais uma instituição em que as pessoas se constituem enquanto ser, pois ali, certos discursos são produzidos ajudando a formatar modos de ser e de se comportar.

Apesar de Michel Foucault ter nascido antes do auge de certas ferramentas tecnológicas presentes em nosso tempo, tais como: internet, smartphones, redes sociais e aplicativos de todos os tipos, seu pensamento no que diz respeito à sociedade de controle e subjetivação nos ajudam a refletir sobre elas.

Para isso, analisamos ao longo desse estudo os aplicativos e sites Tinder e AdoteUmCara a fim de pensar de que modo as pessoas de nosso tempo se utilizam, (ou, são utilizadas), dessas ferramentas a fim de buscar um par com o intuito de se relacionar.

\section{Resultados e Discussão}

Em seu livro Vigiar e Punir, Michel Foucault analisa como os métodos de disciplinar os corpos constituem relações de poder. Para preservarem o controle sobre os indivíduos é preciso que certas instituições apliquem técnicas de docilização de corpos, deixando-os aptos a desempenharem funções sociais específicas dentro das instituições.

Os corpos são modelados pelas instituições: família, escola, quartel, fábrica, hospital, prisão. A disciplina atua por meio de padrões que são consonantes aos interesses políticos e econômicos. Foucault aponta diferentes maneiras de subjetivação que sofrem as mais variadas transformações ao longo da história.

Nesta perspectiva, podemos dizer que as redes sociais seriam novos mecanismos de poder que se baseiam em novas táticas de controle e reprodução dos costumes, remetendo-nos a uma nova maneira de tirania, a virtual.

As redes sociais transformaram nossa sexualidade, uma vez que por meio delas, pode-se conhecer possíveis novos parceiros, compartilhar o status dos nossos relacionamentos, discutir e denunciar questões de gênero presentes em nosso cotidiano (como machismo, homofobia, assédio, propagandas abusivas, etc.).

Essas redes sociodigitais se transformaram em uma vitrine em que o sujeito se relaciona consigo e com o outro como se fosse um produto exposto, a ser comercializado, tendo como dever fazer seu marketing pessoal a partir de selfies e posts atraentes. Sendo assim, quando uma pessoa se interessa por outra, ela 'compra' a imagem vendida na rede.

Para além de coisificar as relações humanas, essas redes sociais influenciam no modo como essas pessoas enxergam umas às outras e a si mesmas, como já dissemos, são uma forma de estabelecer comportamentos, uma vez que seus usuários, tem que se comportar postando fotos e mensagens com as outras obedecendo aos padrões de beleza, consumo e até mesmo de ser e, por isso, uma constituição de subjetividade.

\section{Conclusões}

Ao longo deste trabalho buscamos trazer à luz a discussão sobre algo bastante presente em nossos dias: as redes sociais. Entendemos que essas tecnologias são mais do que um simples veículo para troca de informações, são também, um meio para a formação de identidade, ou seja, subjetivação. Por meio destes mecanismos de poder, são estabelecidos novos comportamentos, corpos são manipulados e sujeitos são constituídos, podendo, assim, ser caracterizar essas redes como novas formas de subjetivação. 